Early iron objects of Southwest China: A case study of iron objects excavated from Qiaogoutou cemetery site, Sichuan Province

${ }^{a}$ School of History and Culture, Sichuan University, Chengdu, Sichuan, China

${ }^{\mathrm{b}}$ Center for Archaeological Science, Sichuan University, Chengdu, Sichuan, China

${ }^{\mathrm{c}}$ Department of Archaeology, University of Exeter, Exeter, Devon, UK

${ }^{*}$ Corresponding author.

E-mail address: xiang0723@ hotmail.com (Yuniu Li), phone: 86-15828243924

10 Abstract: Iron objects excavated from the Qiaogoutou cemetery site provides an opportunity to study

11 iron-making technology during the late Warring States period and the early Western Han dynasty in

12 Southwest China. Five metallographic samples were prepared and analysed. The results are discussed

13 in relation to other studies of iron objects discovered in Southwest China.

14 Keywords: Iron object analyses; early Han dynasty; Qiaogoutou cemetery site; Southwest China.

\title{
16 Acknowledgements
}

17 The authors would like to thank Dr. Donald Wagner for his insightful comments, support and 18 assistance. The comments made by the anonymous reviewers helped to improve the quality of the 19 manuscript and are gratefully acknowledged. This research was funded by The National Social Science 20 Fund of China (No.15ZDB056). 


\section{Introduction}

2 The aim of this paper is to understand the early iron-making technology of Southwest China through 3 the metallographic study of the excavated iron objects from Qiaogoutou. The result is compared with

4 other early iron objects discovered in Southwest China to generate discussion on the origin and 5 development of the iron objects of Qiaogoutou. It addresses the gaps left by the limited previous metallurgical studies of early iron objects of Southwest China.

7 According to archaeological discoveries, cast iron and steel making technologies were established and 8 consolidated in China in the Warring States period (475-221BCE) and the Qin (221-206BCE) and Han 9 dynasties (206BCE-220CE), when iron and steel products were used in many areas (Bai 2005, 116; 10 Han and Ke 2007, 440; Wagner 2007, 115).

11 Southwest China was a separate region distinct from the Central Plain before the Qin conquest of 12 China (221BCE). It was the territory of the Ba, Shu, Dian, Bo, Yelang, and Julan states. Its cultural 13 and technological developments lagged behind but were influenced by the powerful states of the 14 Central Plain. The Qin state conquered the Ba and Shu states in 316BCE, and brought advanced 15 agricultural technology to develop the area so that it could supply its strategic needs. In Shiji ${ }^{1}$, it records 16 that the Qin forced the ancestors of the Zhuo family, smelters from the north of China, to move to Shu 17 when Qin conquered the Zhao state in 222BCE (SiMa 1982, 3277; cf. Wagner 2007, 140-144). This 18 suggests that there was a close connection in both cultural exchange and technology development 19 between Southwest China and the Central Plain during the Warring States period and the Qin and Han 20 dynasties.

21 In the published excavation reports, there are over 5,100 iron objects excavated from Southwest China 22 of all periods, and 2,490 of these are from over 130 sites dated before 200CE. In the past decade, 75 23 iron smelting related sites and locations in the Chengdu plain and Chongqing area have been surveyed 24 or reinvestigated, and 5 among these have been systematically excavated (Ma 2011).

25 However, the scientific analysis and study of excavated iron objects from Southwest China have been 26 limited in comparison with the analysis of material from the Central Plain and northern areas, for example the Mancheng Han tomb (Lu et al. 1980, 369-389), tomb 44 of Yanxiadu (Anonymous 1975),

28 Dabaotai Han tomb (Beijing 1989), and the Dongheishan site (Liu et al. 2014). The location of the

\footnotetext{
1 'Records of the historian', by SiMa Qian, who died 90BCE. This great book tells the history of the known world from mythical beginnings to SiMa Qian's own time.
} 
1 Qiaogoutou site during the Warring States period was near the border of both Shu and Bo states

2 (southern Sichuan and northeast Yunnan provinces). The scientific analyses of its excavated iron

3 objects can provide great value to the study of iron smelting technology of southwest China.

\section{Qiaogoutou}

5 The Qiaogoutou site is located in Yibin city, Sichuan province, China (Fig. 1). It is on the banks of

6 the upper Yangtze River, about $290 \mathrm{~km}$ southeast from Chengdu. The site was discovered by the

7 Sichuan Provincial Cultural Relics and Archaeology Research Institute during fieldwork associated

8 with the construction project of the Xiangjiaba dam in 2006, 2007 and 2009 (Liu 2012). Part of the

9 site, a total area of 2,650 $\mathrm{m}^{2}$ cemetery, was excavated by the Sichuan University in 2011 . The site was

10 long occupied from the Neolithic to the Qing dynasty (1644-1912CE), and the primary remains are

11 from the Warring States period (475-221BCE) to the Qin and Han dynasties (221BCE-220CE). There

12 are 20 pit burials dating from the late Warring States to the early Han dynasty (ca.300-140BCE) which

13 contained gravegoods consisting of assemblages of pottery, bronze and iron objects.

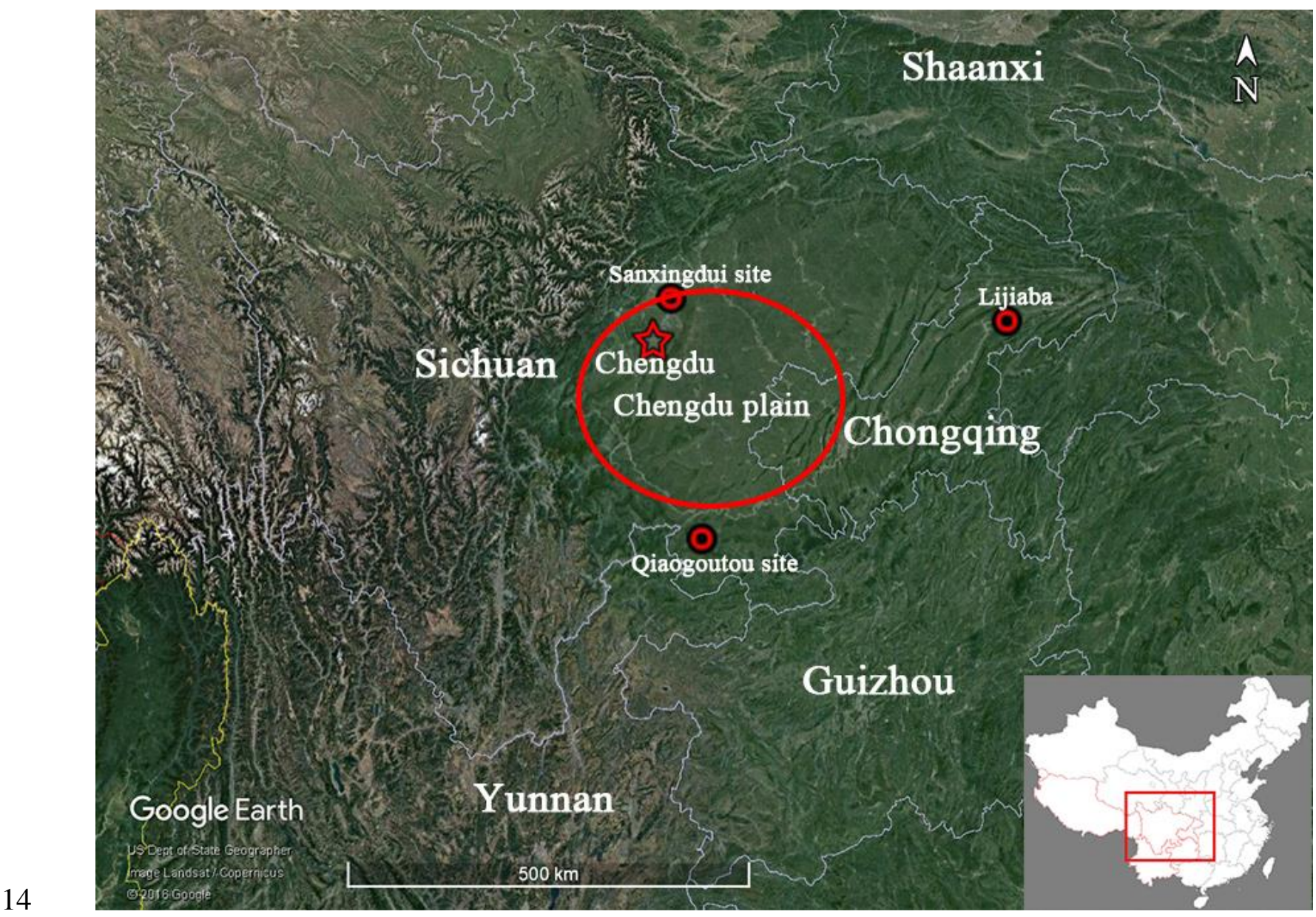


1 A total of 52 iron objects were excavated from 17 tombs, including categories of domestic objects,

2 weapons, tools, accessories and some unidentified (Table 1, Fig. 2). Dating was based on the typical

3 local ceramic assemblage and excavated bronze coins which were retrieved from almost every tomb.

4 All the bronze coins were Banliang coins of the Qin state. 'Banliang', a weight unit of 8g, these typical

5 coins were circulated in the Qin state between 336-206BCE. The ceramics were dated as early as the

6 late Warring States period to the mid-Western Han dynasty (400-140BCE, Liu 2013, 35-37). Bronze

7 coins were discovered in every tomb in which iron objects were excavated. Therefore, the iron objects

8 excavated from Qiaogoutou could be dated to 336-140BCE.

Table 1 Iron objects excavated from Qiaogoutou

\begin{tabular}{|c|c|c|c|}
\hline Category & Type & Count & Percentage \\
\hline Domestic objects & mou (caldron) & 2 & $4 \%$ \\
\hline \multirow{2}{*}{ Weapons } & sword & 10 & \multirow{2}{*}{$27 \%$} \\
\hline & spearhead & 4 & \\
\hline \multirow{4}{*}{ Tools } & axehead & 12 & \multirow{4}{*}{$46 \%$} \\
\hline & implement cap & 8 & \\
\hline & sicklehead & 2 & \\
\hline & knife & 2 & \\
\hline Accessories & belt hook & 1 & $2 \%$ \\
\hline Others & unidentified & 11 & $21 \%$ \\
\hline & Total & 52 & \\
\hline
\end{tabular}

10 


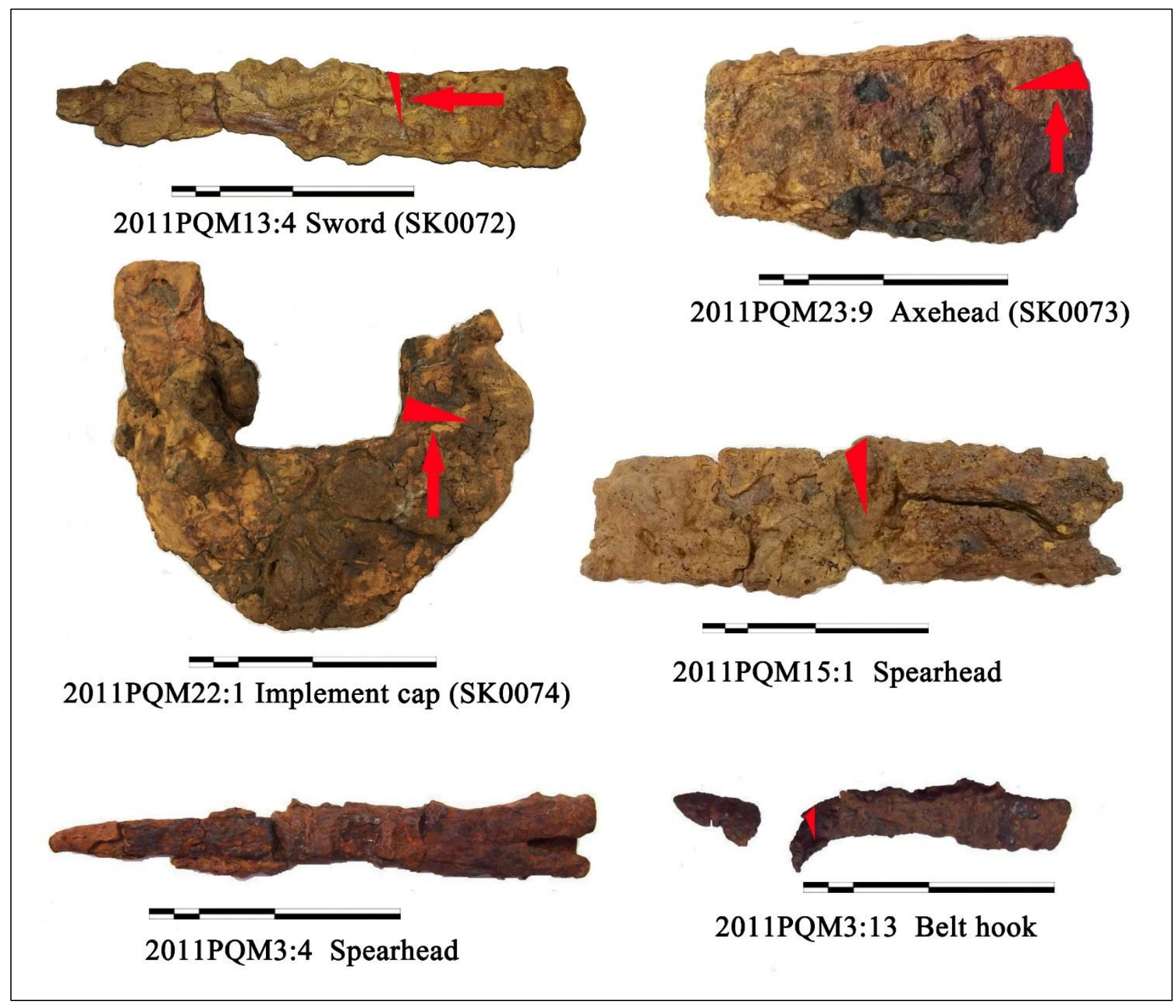

Fig. 2 Examples of iron objects from Qiaogoutou cemetery showing sampling positions

\section{Methodology}

4 Five samples were prepared and analysed, of these two were fully corroded with no metal remaining.

5 The samples were taken by making two cuts inward to meet close to the central area of the object. The

6 specimens were compression mounted at $30 \pm 5 \mathrm{MPa}$ and $130 \pm 5^{\circ} \mathrm{C}$, ground and polished. The polished

7 sections were examined using a Leica CM6000M optical microscope before and after etching with $2 \%$

8 nital. SEM-EDS analyses were carried out with an Oxford X-Max ${ }^{\mathrm{N}} 50 \mathrm{~mm} 2$ EDS system at the Jinsha

9 Museum in Chengdu, China, and the acceleration voltage was set to $20 \mathrm{kV}$ (Table 2). The points/areas

10 analysed are labeled in the figures and the results were shown in Table 3. We acknowledge the

11 limitation that only 3 samples were studied, but the excavated iron objects from Qiaogoutou were

12 badly corroded and the density of most of the iron objects was very low. Two cuts were made on two

13 of these low density objects but there was no metal remaining, thus we stopped cutting these low 
1 density objects. Fortunately, three higher density objects were found to have enough metal remaining

2 for metallographic examination.

Table 2 Sample analysis details from Qiaogoutou.

\begin{tabular}{|c|l|c|c|c|}
\hline Artifact No & \multicolumn{1}{|c|}{ Type } & Laboratory No & $\begin{array}{c}\text { Metallographic } \\
\text { analysis }\end{array}$ & SEM-EDS \\
\hline 2011PQM15:1 & spearhead & - & NO & NO \\
\hline 2011PQM3:13 & belt hook & - & NO & NO \\
\hline 2011PQM13:4 & sword & SK0072 & YES & YES \\
\hline 2011PQM23:9 & axehead & SK0073 & YES & YES \\
\hline 2011PQM22:1 & $\begin{array}{l}\text { U-shaped } \\
\text { implement cap }\end{array}$ & SK0074 & YES & YES \\
\hline
\end{tabular}

4

\section{Results}

6 A summary of the metallographic analysis of the three samples is given in Table 4 and more detailed 7 descriptions are given below.

\section{Sample SK0072}

9 This sample is cut from the cross section of an iron sword. The sword is almost fully corroded with 10 very little metal remaining in the core (about $0.6 \mathrm{~cm}$ wide and $0.1-0.2 \mathrm{~cm}$ thick). Some slag inclusions, 11 single-phased, could be seen in the unetched section. Most were seen as narrow stringers aligned in a 12 direction parallel to the surfaces (Fig. 3). 


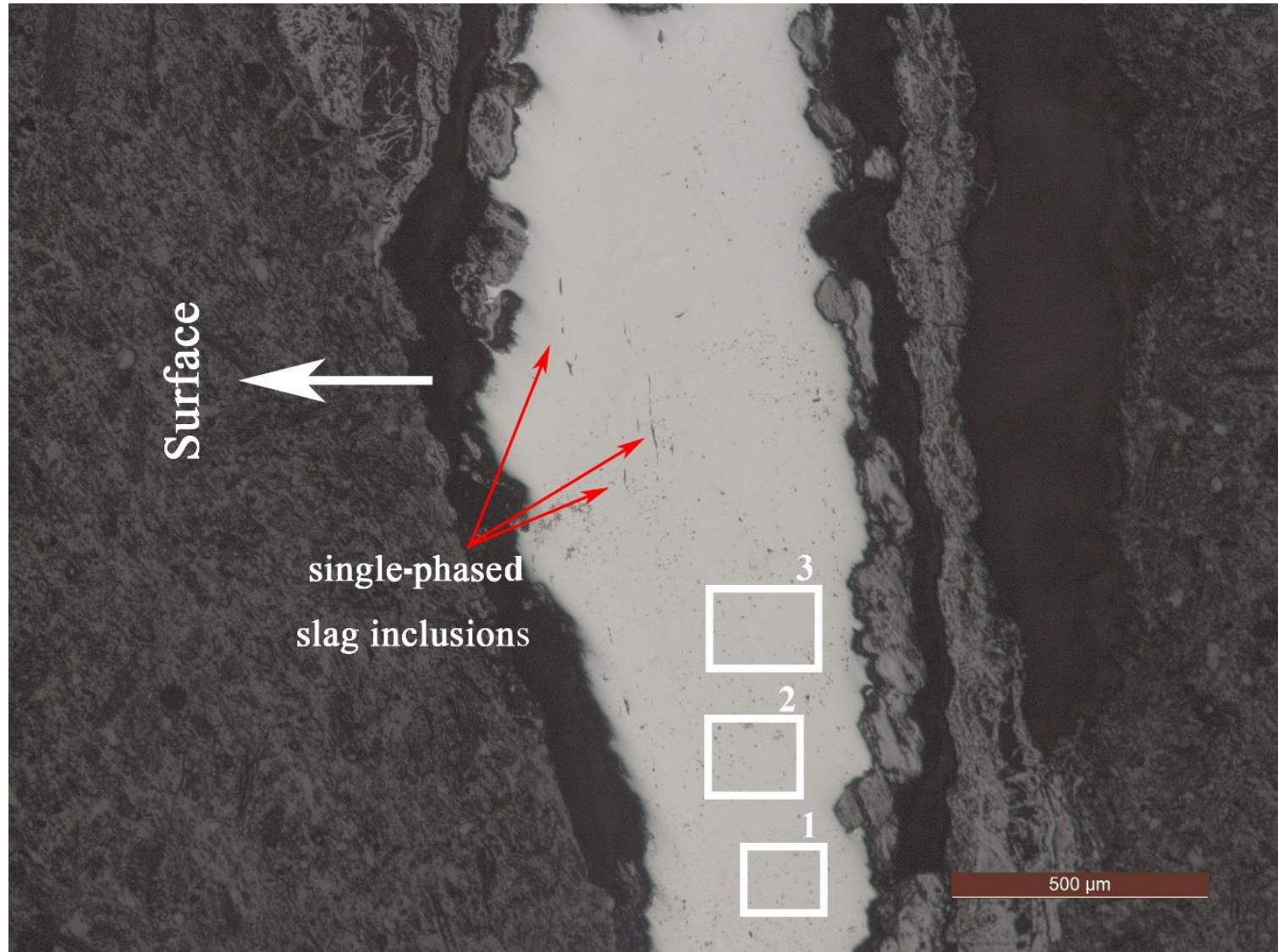

Fig. 3 SK0072 showing the remaining metal, the distribution of the inclusions, and areas for composition analyses. Unetched. Scale bar 500 $\mu \mathrm{m}$.

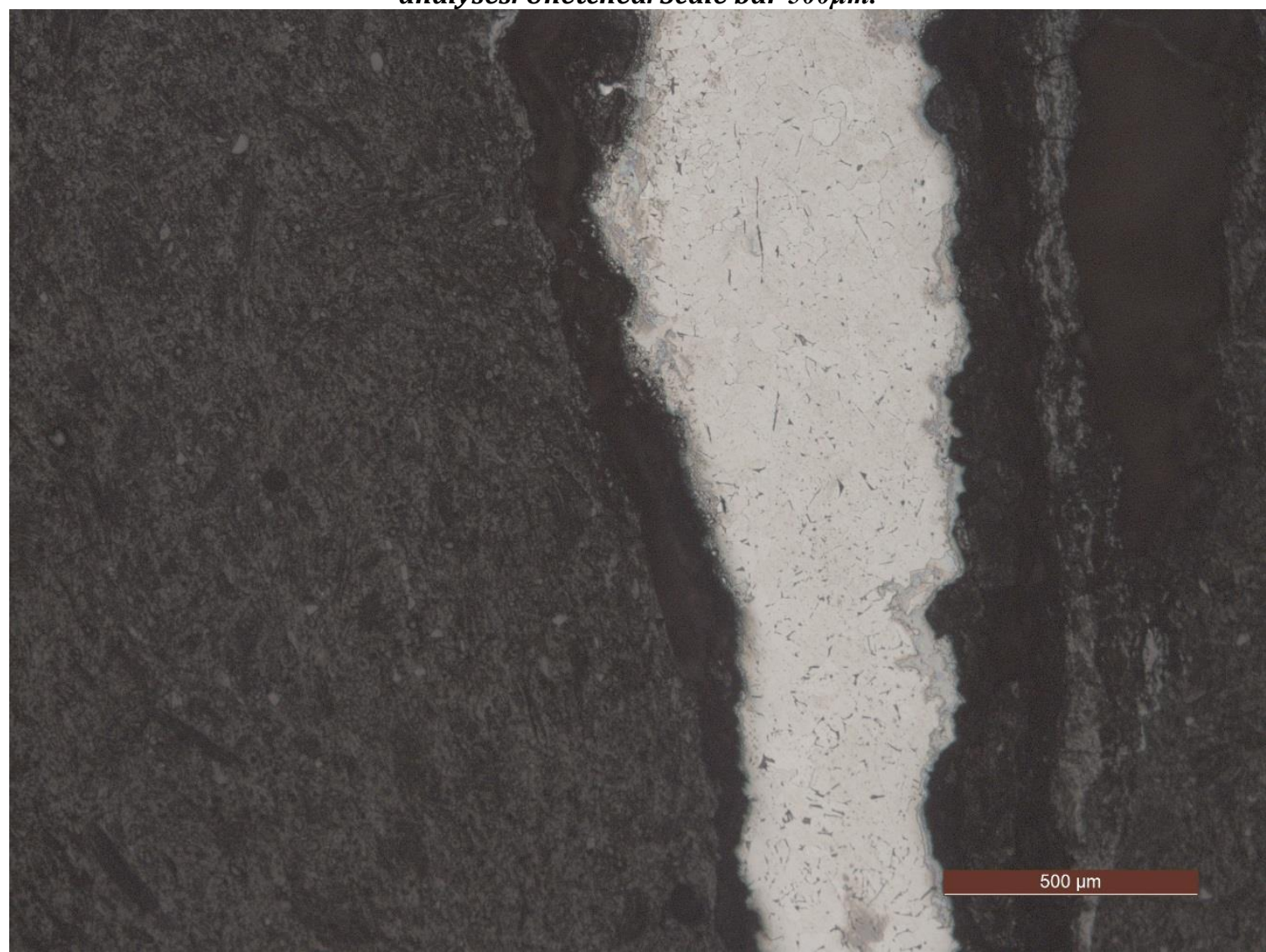

Fig. 4 SK0072. Small grains, not very clear grain boundaries. Ferrite with a slightly uneven response, suggesting phosphorus, grain boundary pearlite and stringers. Etch $2 \%$ nital. 
1 At low magnification, etching revealed a ferrite matrix with small grain size, and some light

2 precipitates within the ferrite grains. The grain boundaries are faint, and a slightly uneven response to

3 etching was visible throughout the section (Fig. 4). It is of low carbon content, $0.1 \%$, with grain

4 boundary cementite and a little pearlite (Fig. 5). Grain sizes and orientation are even and give no

5 obvious clues of working deformation.

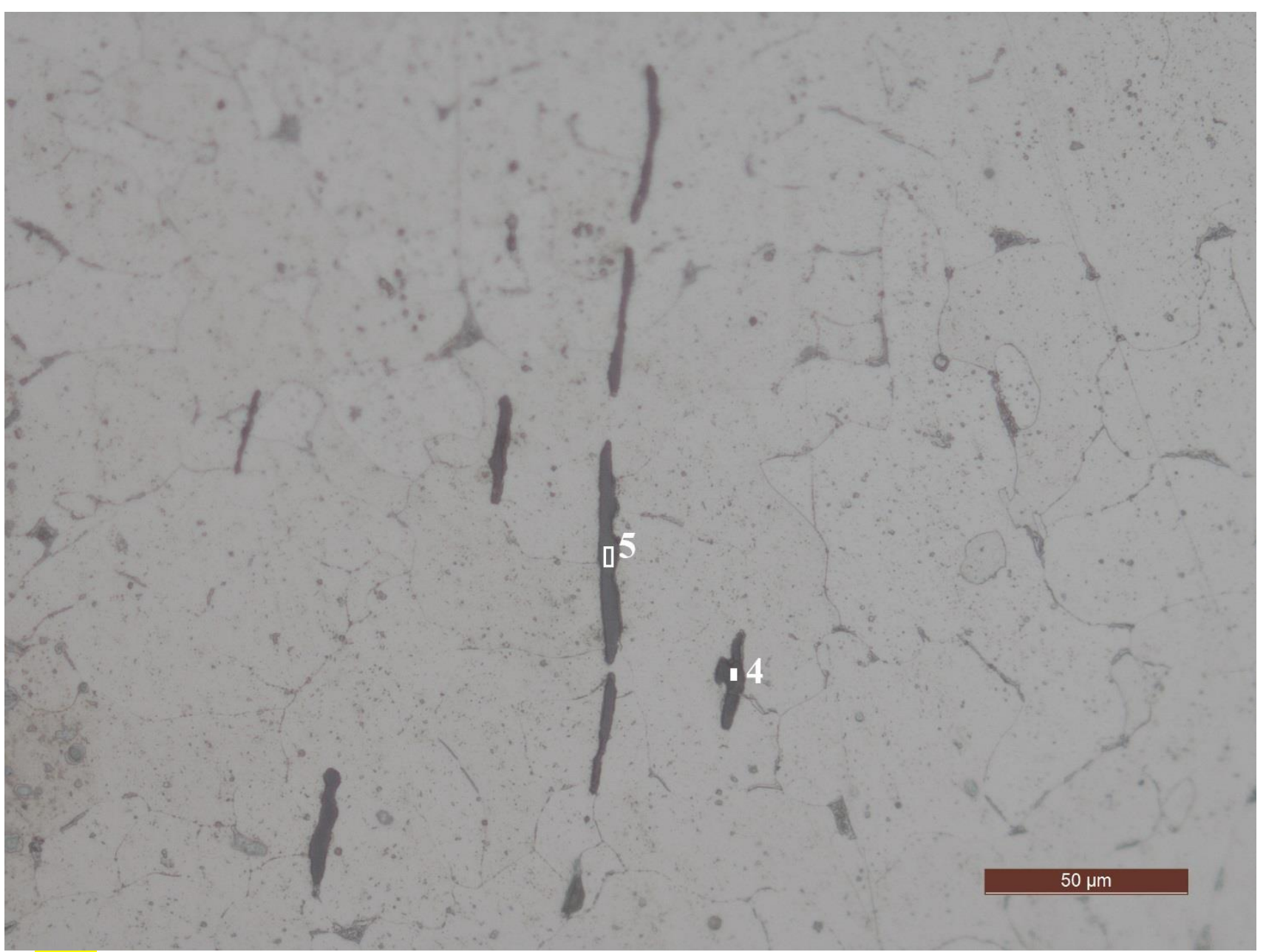

Fig. 5 SK0072 showing the distribution of the stringers, low occurrence of carbon distributed along with grain boundaries, and areas for composition analyses. Etch $2 \%$ nital.

\section{Sample SK0073}

10 This sample is cut from the cutting edge of an iron axehead. One side of the sample shows a band of

11 corrosion within the remaining metal. The corrosion is dark and light grey in colour. Both single and

12 double-phased slag inclusions could be seen before etching (Fig. 6 ). The single-phased slag inclusions

13 are relatively small, elongated, and distributed in groups parallel to the surface. The double-phased

14 slag inclusions are larger, mainly elongated with some irregular exceptions, and also distributed

15 parallel to the surface. The double-phased slag inclusions have dark and light grey phases which could

16 be identified as an iron silicate (fayalitic) matrix with wüstite dendrites (Fig. 8). 


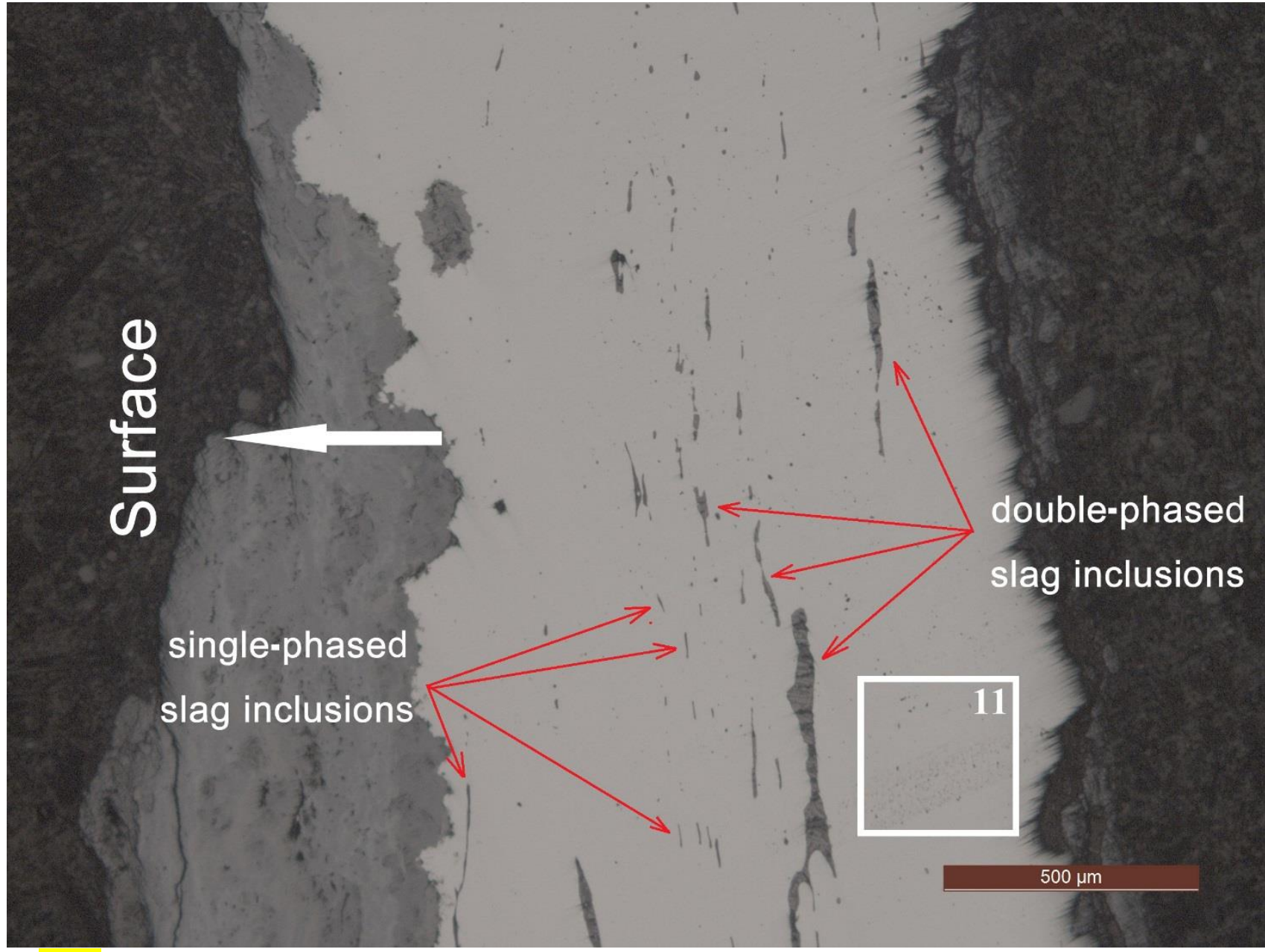
analysis. Unetched. Scale bar 500 $\mu \mathrm{m}$.

4 At low magnification, etching revealed a fine pearlite matrix. The structure near the tip area is pure 5 pearlite. Ferrite started forming on the edge of the grain boundaries away from the tip area. The amount 6 of ferrite increased from the tip to the middle and from one surface to the other surface of the axehead. 7 The carbon content is ca. $0.2 \%-0.4 \%$ in the top right corner in Fig. 7. Needle-like ferrite structures 8 extend inwards from the grain boundaries, indicating a Widmanstätten structure. The grains are 9 equiaxed without distortion (Fig. 8). 


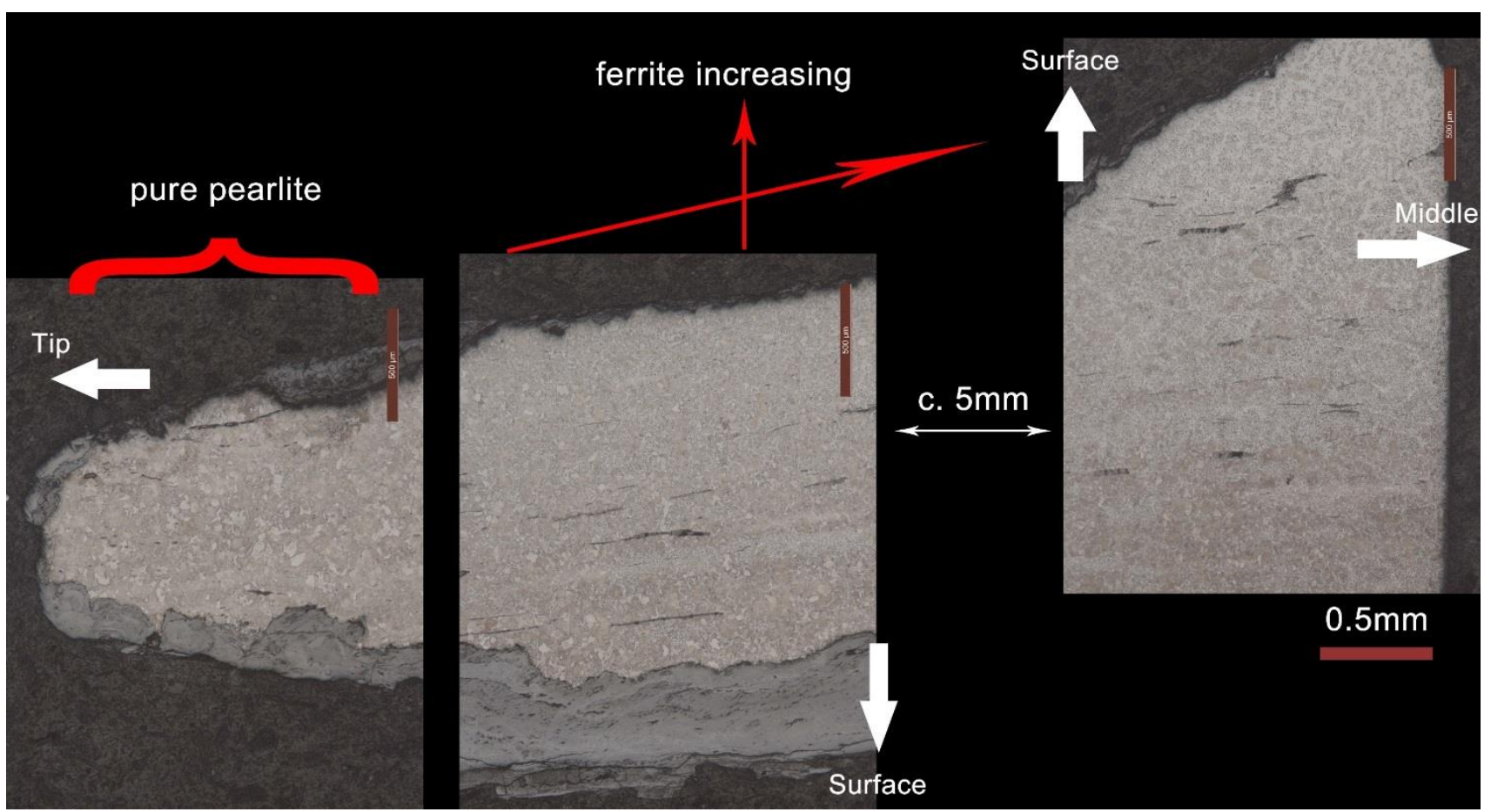

Fig. 7 Montage of the section from SK0073 showing the difference of carbon content in different areas of the object. Etch $2 \%$ nital.

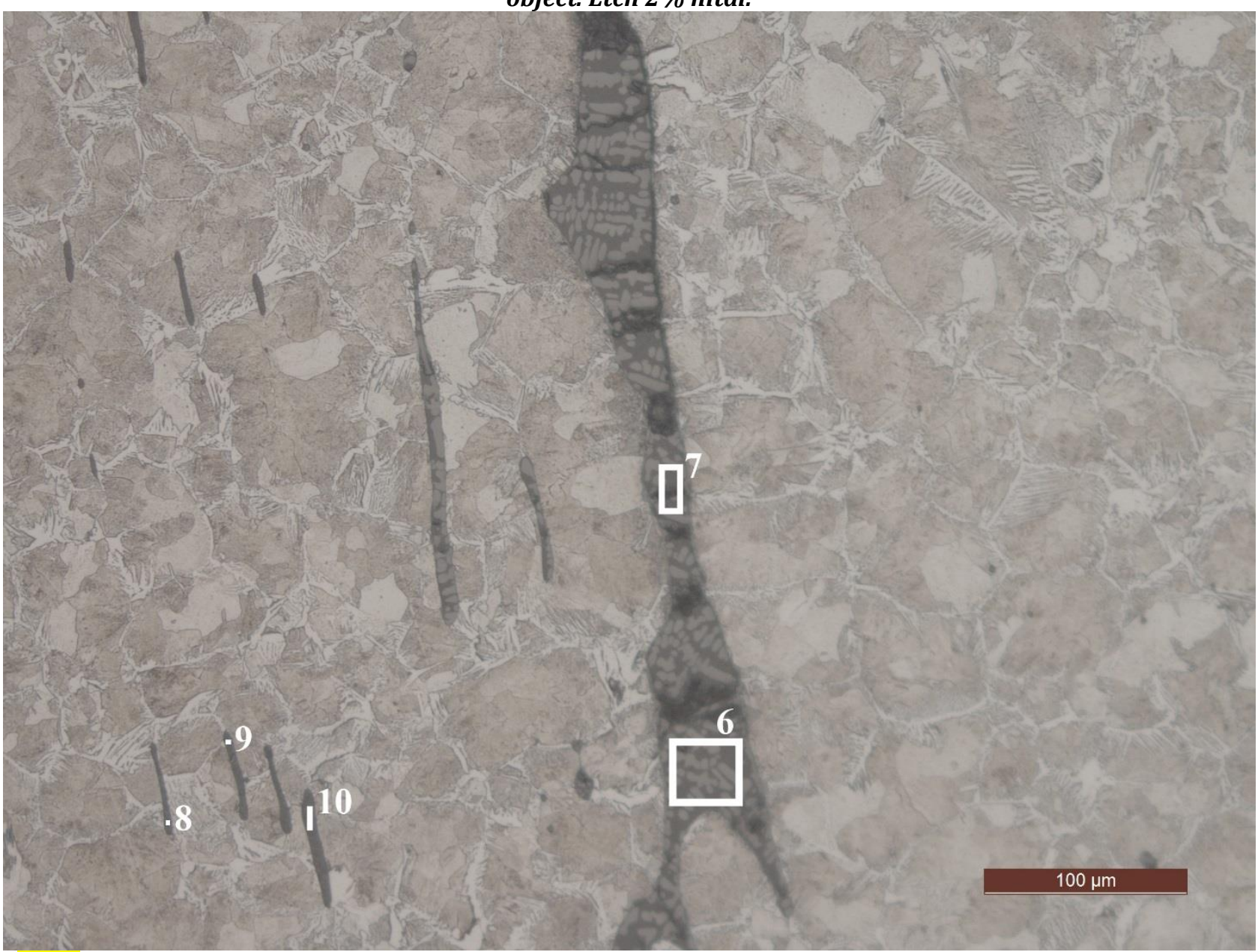

Fig. 8 SK0073 showing the ferrite and pearlite matrix, the distribution of the inclusions, a Widmanstätten precipitation of ferrite into pearlite containing grains, and areas for composition analyses. Etch $2 \%$ nital. 


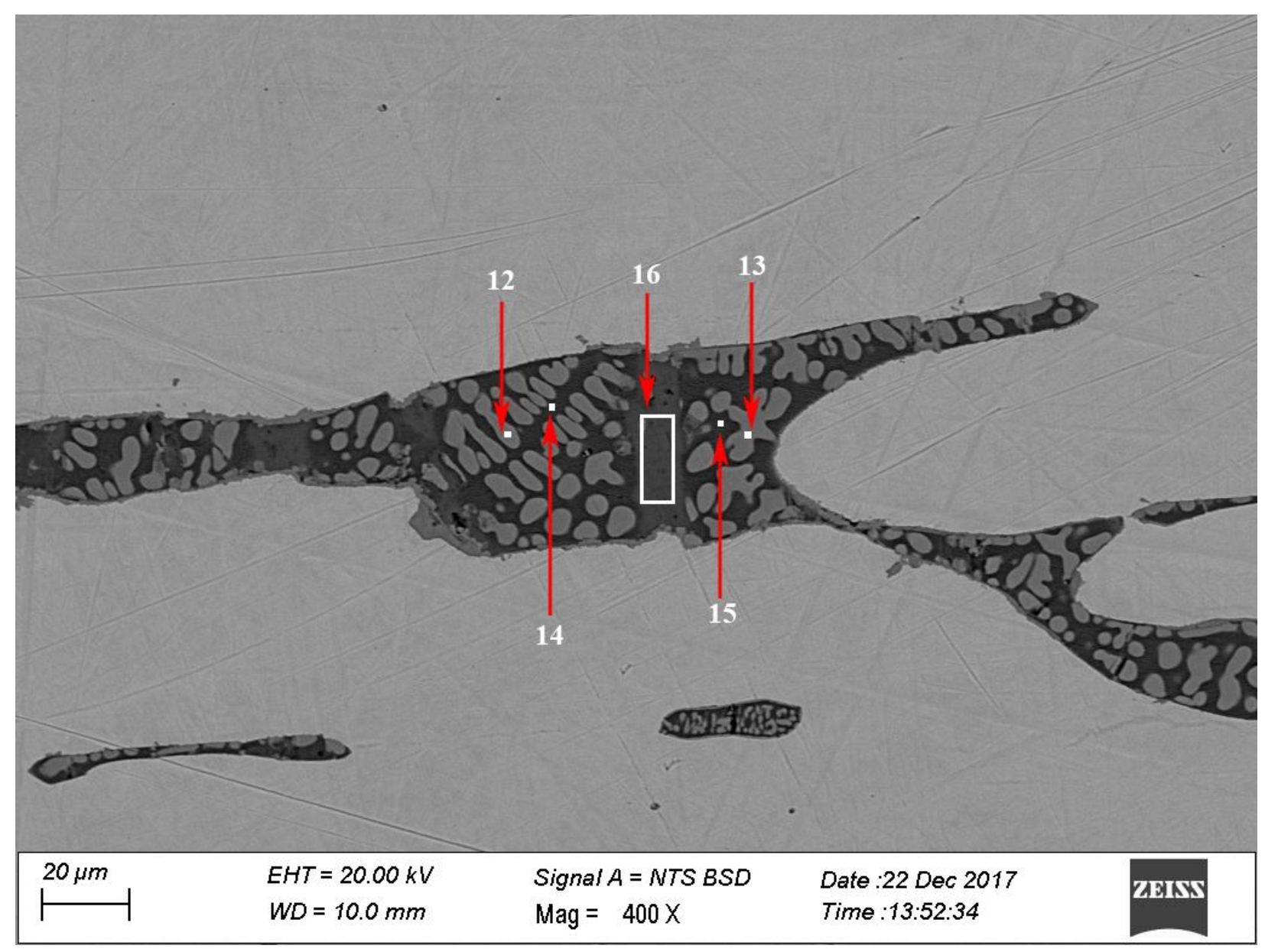

Fig. 9 SK0073 showing the double-phased slag inclusions and areas for composition analyses.

\section{Sample SK0074}

5 This sample is cut from the edge of a U-shaped iron implement cap. The sample is badly corroded with

6 very little metal left in the centre.

7 At low magnification, etching revealed a ferrite matrix and clear grain structure with different size 8 grains. The rust in the middle of the sample was from imperfect drying during sample preparation.

9 There were no visible slag inclusions or grain distortion that might indicate forging. There are some 10 graphite-like structures throughout the section (Fig. 10). 


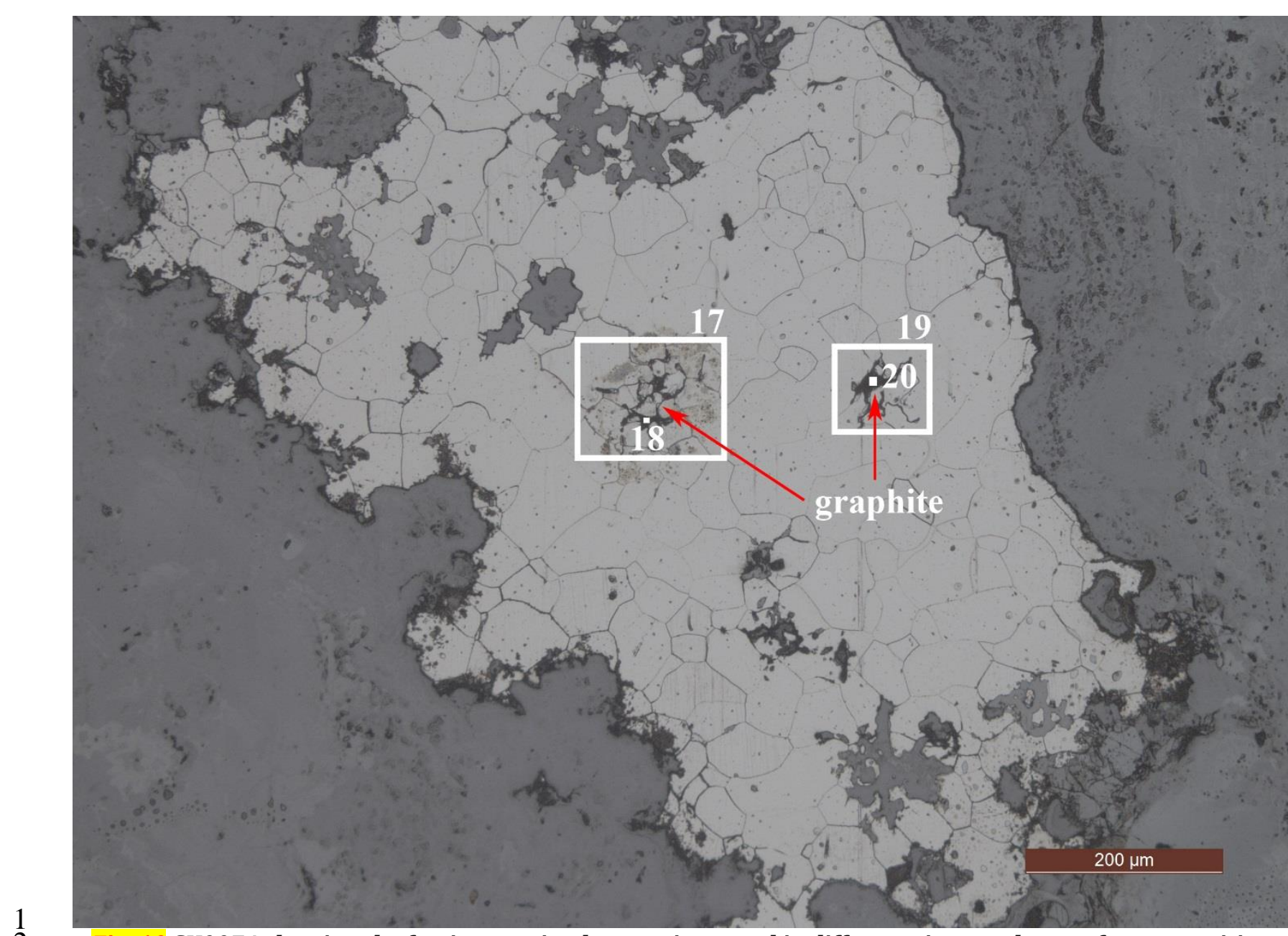

Fig. 10 SK0074 showing the ferrite matrix, clear grain crystal in different sizes, and areas for composition analyses. Etch $2 \%$ nital.

Table 3 Result of chemical compositions (normalized wt\%)

\begin{tabular}{|c|c|ccccccccccccc|}
\hline $\begin{array}{c}\text { Sample } \\
\text { no. }\end{array}$ & $\begin{array}{c}\text { Analysis } \\
\text { no. }\end{array}$ & $\mathrm{C}$ & $\mathrm{O}$ & $\mathrm{Na}$ & $\mathrm{Mg}$ & $\mathrm{Al}$ & $\mathrm{Si}$ & $\mathrm{P}$ & $\mathrm{Cl}$ & $\mathrm{K}$ & $\mathrm{Ca}$ & $\mathrm{Ti}$ & $\mathrm{Mn}$ & $\mathrm{Fe}$ \\
\hline SK0072 & 1 & 3.3 & - & - & - & - & - & - & - & - & - & - & - & 96.7 \\
& 2 & 3.8 & - & - & - & - & 0.5 & - & - & - & - & - & - & 95.7 \\
& 3 & 3.8 & - & - & - & - & - & - & - & - & - & - & - & 96.3 \\
& 4 & 5.6 & 24.3 & 0.5 & 1.8 & 3.1 & 16.9 & - & - & 1.7 & 6.0 & 0.6 & 2.3 & 37.3 \\
& 5 & 4.3 & 41.0 & - & 1.0 & 2.2 & 22.9 & 0.1 & - & 2.3 & 5.0 & 0.4 & 2.9 & 17.3 \\
\hline SK0073 & 6 & 12.8 & 25.3 & - & - & 1.0 & 5.2 & 0.5 & 0.4 & 0.6 & 1.1 & - & - & 53.1 \\
& 7 & 23.0 & 22.5 & - & 0.4 & 1.0 & 4.9 & 0.6 & 0.1 & 0.7 & 1.1 & - & - & 45.9 \\
& 8 & 27.4 & 26.2 & - & 0.7 & 1.3 & 8.1 & 1.3 & - & 1.7 & 5.1 & - & 1.0 & 27.3 \\
& 9 & 36.6 & 24.1 & - & 0.5 & 1.3 & 7.9 & 1.3 & - & 2.1 & 4.2 & - & 0.8 & 21.3 \\
& 10 & 26.2 & 23.9 & - & 0.6 & 1.6 & 8.6 & 1.3 & - & 2.0 & 6.2 & 0.2 & 1.0 & 28.6 \\
& 11 & 4.1 & - & - & - & - & - & - & - & - & - & - & - & 95.9 \\
& 12 & 5.0 & 23.2 & - & - & 0.5 & 2.2 & 0.3 & - & - & 0.4 & - & - & 68.3 \\
& 13 & 9.3 & 24.6 & - & 0.6 & 1.3 & 6.8 & 0.7 & - & 0.5 & 1.1 & - & - & 55.2 \\
& 14 & 11.1 & 31.6 & - & 0.6 & 2.0 & 11.9 & 1.3 & - & 1.5 & 2.8 & - & - & 37.2 \\
& 15 & 11.4 & 29.9 & - & 0.7 & 2.0 & 10.6 & 1.3 & - & 1.2 & 2.4 & - & - & 40.5 \\
& 16 & 5.3 & 32.8 & - & - & - & - & - & 5.0 & - & - & - & - & 56.9 \\
\hline SK0074 & 17 & 5.0 & - & - & - & - & 0.4 & 0.4 & - & - & - & - & - & 94.2 \\
& 18 & 29.0 & 9.8 & - & - & - & 0.5 & 0.3 & - & - & 0.2 & - & - & 60.2 \\
& 19 & 6.6 & - & - & - & - & 0.3 & 0.5 & - & - & - & - & - & 92.7 \\
& 20 & 60.3 & 18.8 & - & - & - & 0.6 & 0.1 & - & - & 0.6 & - & - & 19.6 \\
\hline
\end{tabular}

Notes: '-' means below detection limit. 


\section{Discussion of the results}

2 The slag inclusions in SK0072 are fewer and smaller than the slag inclusions in SK0073. The acicular 3 phases in the ferrite grains of SK0072 are either carbides, nitrides or carbide-nitrides (Scott 2013, 167).

4 The carbon content is very low in SK0072, less than $0.1 \%$. The single-phased slag stringers and 5 undistorted grains in SK0072 suggests that the object was forged and annealed from wrought iron. 6 When making iron swords, the blacksmiths of ancient China probably started with wrought iron, and carburized the sword during the forging process. In ancient China, wrought iron could have been produced in a number of different ways - by a bloomery process, a crucible process, by the fining of pig iron from a blast furnace, or by solid-state decarburization of pig iron from a blast furnace (Wagner 1993, 288). There is still insufficient evidence of a crucible process for iron smelting in China before 200CE (Zhou et al. 2016, 363), and we might expect more and larger slag inclusions if the wrought iron was from a bloomery process. It is possible to produce wrought iron by fining pig iron from a blast furnace although the primary purpose of this process was to produce carbon steel. In addition, the high silica single-phased slag inclusions may indicate the wrought iron used to forge this sword was probably from solid-state decarburization of pig iron, which the iron was cast into a plate or rod and annealed in an oxidizing atmosphere, decarburizing it in the solid state.

The slag stringers and the decreasing pearlite from the tip to the middle of SK0073 suggest that the object was forged from wrought iron and then carburized to a medium-high carbon steel. Some scholars believe slag inclusions can be used to identify the material is either bloomery iron or fined iron (Chen and Han 2007, 37; Liu 2014, 60). According to their definition and the SEM-EDS result of SK0073 (Table 3, analysis no.6-16), the material could be identified as bloomery iron because the clear eutectoid phase-separated microstructure as in bloomery iron's high Fe and low Si double-phased inclusions, however, it could also be identified as fined iron (or puddled steel as defined by Liu 2014) because there are also many single-phased inclusions. Therefore, in this case this method may not yet be a sufficient way to identify bloomery iron and fined iron.

There is only very little metal left in the center of SK0074. No conclusive evidence of either forging or casting was discovered. However, this type of implement is usually believed to be cast rather than forged in ancient China. The SEM-EDS result indicated that the graphite-like structures are very possibly graphite (Table 3, analysis no.17-20). The artefact was possibly made from whiteheart malleable cast iron, being cast in white cast iron and then decarburized in the solid-state. A small amount of pearlite and more graphite could be expected in a larger sample. 
Table 4 Iron objects from Qiaogoutou. Summary of metallographic analysis.

\begin{tabular}{|c|c|c|c|c|}
\hline Artifact No & Laboratory No & Phases & Carbon & $\begin{array}{c}\text { Material and } \\
\text { techniques }\end{array}$ \\
\hline 2011PQM13:4 & SK0072 & ferrite & $\begin{array}{c}\text { some carbon on grain } \\
\text { boundary }\end{array}$ & $\begin{array}{c}\text { wrought iron, solid- } \\
\text { state decarburized, } \\
\text { forged, annealed }\end{array}$ \\
\hline 2011PQM23:9 & SK0073 & ferrite, pearlite & $\begin{array}{c}\text { decreasing from tip to } \\
\text { middle, and one surface to } \\
\text { the other. Low to 0.2- } \\
0.4 \%, \text { and high to 0.6- } \\
0.77 \%\end{array}$ & $\begin{array}{c}\text { wrought iron, hypo- } \\
\text { eutectoid steel, } \\
\text { forged }\end{array}$ \\
\hline 2011PQM22:1 & SK0074 & ferrite & some graphite & $\begin{array}{c}\text { whiteheart } \\
\text { malleable cast iron }\end{array}$ \\
\hline
\end{tabular}

\section{Discussion}

4 Metallographic studies of iron objects dating to the $5^{\text {th }}$ century BCE or earlier have concluded that the

5 blades of iron swords (with bronze or jade handles) were made from carburized bloomery iron with a

6 carbon content up to $0.5 \%$ (Han 1998, 92). Other metallographic studies of iron swords, axeheads, and

7 U-shaped implement caps from the $4^{\text {th }}$ century BCE to the $4^{\text {th }}$ century CE are listed in Table 5. However,

8 most of the analyses were published a long time ago, and it remains unclear how the investigators

9 arrived at their conclusions. Many also have no illustrations of the microstructures. Therefore, it is

10 preferable to exclude the conclusions and only focus on their descriptions.

11 From these descriptions (Table 5), the materials used to make these iron swords were hypo-eutectoid

12 steel with carbon content usually higher near the surface from $0.3 \%$ to $0.8 \%$ and lower in the core from

$130.1 \%$ to $0.3 \%$, and sometimes quenched. The axeheads were made of decarburized steel from white

14 cast iron with a carbon content between $0.2 \%$ to $0.4 \%$, and the earlier two (the $4^{\text {th }}$ to $2^{\text {nd }}$ century BCE)

15 were forged and the later (200-350CE) were cast. There are only few single-phased slag inclusions

16 found in these axeheads. The U-shaped implement caps were made of varied materials including white

17 cast iron, decarburized steel from white cast iron, and malleable cast iron.

18 As we know now, the iron objects excavated at Qiaogoutou were made from wrought iron and

19 whiteheart malleable cast iron. It is interesting that wrought iron tools were found in Sichuan. Wagner

$20(1993 ; 2007)$ has pointed out in his works that in early times in China, weapons were wrought and

21 tools were cast, and that this began to change in the Tang dynasty (618-907CE). There are some 
1 exceptions, for example, an iron scythe-blade from a Han tomb excavated in Mianyang (near Chengdu),

2 Sichuan province (Wagner 1993, 212), a similar scythe-blade of Han dynasty was excavated at Lijiaba,

3 Chongqing, and the iron axehead (SK0073) from Qiaogoutou were all wrought iron tools. These exceptions might be helpful in studying the differences in policy and management of the central government and the frontier areas relating to iron production technology.

6 Up to now, there have been very few metallurgical studies of excavated iron objects from Southwest 7 China. Li Xiaocen (2011) analyzed some iron objects from Yunnan, and the results show that there were both forged and cast iron in use. The forged iron objects appeared no later than the mid-late

9 Warring States period (ca.340-200BCE). The quantity and type of both are few and include iron 10 bracelet, iron knife, iron sword (bronze handle) and iron chisel (bronze socket) indicating iron may 11 have been regarded as a precious material at the time. In addition, hypo-eutectoid steel objects were 12 also in use. However, there is no evidence of iron smelting activities in ancient Yunnan before the mid13 Western Han dynasty (ca.140-50BCE), and the iron objects and primary material were possibly 14 imported from Sichuan or further afield. Iron was widely applied in the making of tools and weapons 15 in ancient Yunnan during the mid-late Western Han dynasty (ca.140BCE-9CE). Many puddled steel, 16 quenched steel and cast iron objects were discovered in tombs indicating a big improvement of iron 17 making technology ( $\operatorname{Li} 2011,99)$.

18 Chen Jianli et al. (2008a, 195-206) analyzed 11 iron objects (one iron sword with bronze handle) 19 excavated from Kele, Guizhou province. The objects are dated from the late Warring States period to 20 the early Han dynasty (300-150BC). The result shows that the objects were both forged and cast, and 21 the materials and included white cast iron (decarburized to steel and wrought iron), malleable cast iron, 22 bloomery iron, and fined iron. They concluded that iron production technology of Kele, Guizhou, 23 derived from the Central Plains technology system (Chen et al. 2008a, 206).

24 Li Yingfu (2016) analyzed a bridge pier weighing 1.38 tons and dated 96BCE, discovered in Guanghan, 25 Sichuan. The metallographic results show the artefact is grey-cast iron, and nearby were found 26 fragments of the mould in which it was cast. It is direct evidence indicating that the ancient Sichuan 27 was capable of casting big iron objects at least by 96BCE. 
1 The Qiaogoutou site is located in the south of Sichuan province close to Yunnan province. The iron

2 objects analyzed here were dated to the late Warring States period and early Western Han dynasty

3 (336-140BCE). The metallographic characteristics of these objects are similar to the ones discovered

4 in Yunnan of the same period, but in larger quantity and more types including weapons, tools and

5 domestic objects. However, it is still too early for conclusions to be drawn about the iron production

6 technology until more samples can be studied.

\section{Conclusion}

8 The iron objects excavated from Qiaogoutou are abundant both in quantity and type. Three

9 metallographic samples, one each from a weapon, a wood working tool, and an agricultural implement

10 were analyzed. The analysis provides valuable data for the study of iron making and smelting in

11 southwest China. According to the metallographic results, during the Warring States period and the

12 Western Han dynasty the primary use of iron at Qiaogoutou is forged wrought iron objects. There is

13 also evidence that cementation, annealing (SK0072) and decarburization (SK0074) were used.

14 However, it is worth mentioning that these artefacts were all excavated from cemetery contexts, which

15 could not be fully representative of daily use situations. In addition, there is no evidence of iron

16 smelting in this area. To address the question whether they were made locally or imported from other

17 places will require more samples to be studied in the future. Qiaogoutou is a large cemetery site, the

18 richness of the object types and its production level is greater than in the Yunnan area generally, but

19 lower than the contemporary discoveries from the Chengdu plain and Lijiaba (author, manuscript in

20 preparation). The emerging picture is that Qiaogoutou was possibly an important routeway of contact

21 between the Shu and Ba regions and areas further southwest. 


\begin{tabular}{|c|c|c|c|c|c|c|c|c|c|}
\hline No. & Lab No. & Context & $\begin{array}{c}\text { Cutting } \\
\text { point }\end{array}$ & Type & Date & Area & Description * & Conclusion & Source \\
\hline 1 & 7117 & M374:15 & $\begin{array}{l}\text { cutting } \\
\text { edge }\end{array}$ & sword & $\begin{array}{l}200-350 \\
\mathrm{CE}\end{array}$ & $\begin{array}{l}\text { Liaoning } \\
\text { (northeast) }\end{array}$ & $\begin{array}{l}\text { pure pearlite in the cutting edge area, } 0.8 \% \text { carbon; } \\
\text { core area about } 0.3 \% \text { carbon with a Widmanstätten } \\
\text { structure; slag stringers, carburized on the edge. }\end{array}$ & fined steel, forged & \multirow{6}{*}{$\begin{array}{l}\text { (Chen et al. } \\
\text { 2001) }\end{array}$} \\
\hline 2 & 7118 & M218:10 & $\begin{array}{l}\text { cutting } \\
\text { edge }\end{array}$ & sword & $\begin{array}{l}200-350 \\
\mathrm{CE}\end{array}$ & $\begin{array}{l}\text { Liaoning } \\
\text { (northeast) }\end{array}$ & $\begin{array}{l}\text { uneven carbon content distribution, higher on the } \\
\text { edge with a Widmanstätten structure, } 0.3 \% \text { carbon, } \\
\text { carburized. Core area is ferrite and small amount of } \\
\text { pearlite on the grain boundaries, } 0.1 \% \text { carbon, } \\
\text { single and sub-double phases inclusion stringers } \\
\text { mostly in the core area. }\end{array}$ & fined steel, forged & \\
\hline 3 & 7119 & M309:13 & $\begin{array}{l}\text { cutting } \\
\text { edge }\end{array}$ & sword & $\begin{array}{l}200-350 \\
\mathrm{CE}\end{array}$ & $\begin{array}{l}\text { Liaoning } \\
\text { (northeast) }\end{array}$ & $\begin{array}{l}\text { uneven carbon content distribution, higher side is } \\
\text { ferrite+pearlite on the grain boundaries, } 0.1 \% \\
\text { carbon, lower side is ferrite, single-phased } \\
\text { inclusion stringers. }\end{array}$ & $\begin{array}{l}\text { fined steel, cold } \\
\text { forging }\end{array}$ & \\
\hline 4 & 7112 & M4:46 & $\begin{array}{c}\text { cutting } \\
\text { edge }\end{array}$ & axehead & $\begin{array}{c}200-350 \\
\mathrm{CE}\end{array}$ & $\begin{array}{c}\text { Liaoning } \\
\text { (northeast) }\end{array}$ & $\begin{array}{l}\text { even carbon distribution, pearlite+ferrite, } 0.4 \% \\
\text { carbon, few inclusions. }\end{array}$ & $\begin{array}{l}\text { decarburized steel } \\
\text { from white cast iron }\end{array}$ & \\
\hline 5 & 7131 & M205:11 & $\begin{array}{l}\text { cutting } \\
\text { edge }\end{array}$ & axehead & $\begin{array}{l}200-350 \\
\mathrm{CE}\end{array}$ & $\begin{array}{l}\text { Liaoning } \\
\text { (northeast) }\end{array}$ & $\begin{array}{l}\text { ferrite+pearlite, pearlite precipitated on the ferritic } \\
\text { grain boundaries, } 0.2 \% \text { carbon, very few inclusions, } \\
\text { shrinkage cavities or gas hole in casting. }\end{array}$ & $\begin{array}{l}\text { decarburized steel } \\
\text { from white cast iron, } \\
\text { cast }\end{array}$ & \\
\hline 6 & 7134 & M20:4 & $\begin{array}{l}\text { cutting } \\
\text { edge }\end{array}$ & $\begin{array}{l}\text { U-shaped } \\
\text { implement } \\
\text { cap }\end{array}$ & $\begin{array}{l}200-350 \\
\mathrm{CE}\end{array}$ & $\begin{array}{l}\text { Liaoning } \\
\text { (northeast) }\end{array}$ & white cast iron, casting flaws. & white cast iron & \\
\hline 7 & FWC01 & (3): 18 & & $\begin{array}{l}\text { U-shaped } \\
\text { implement } \\
\text { cap }\end{array}$ & $\begin{array}{l}-4 \text { th/-2nd } \\
\text { century }\end{array}$ & $\begin{array}{l}\text { Fujian } \\
\text { (southeast } \\
\text { coast) }\end{array}$ & $\begin{array}{l}\text { badly corroded, trace of white cast iron structure in } \\
\text { the corrosion. }\end{array}$ & white cast iron & \multirow{4}{*}{$\begin{array}{l}\text { (Chen et al. } \\
\text { 2008b) }\end{array}$} \\
\hline 8 & FWC02 & T13II(3):4 & & $\begin{array}{l}\text { U-shaped } \\
\text { implement } \\
\text { cap }\end{array}$ & $\begin{array}{l}-4 \text { th/-2nd } \\
\text { century }\end{array}$ & $\begin{array}{l}\text { Fujian } \\
\text { (southeast } \\
\text { coast) }\end{array}$ & $\begin{array}{l}\text { badly corroded, little metal left, which is pearlite } \\
\text { with } 0.8 \% \text { carbon content, no inclusion. }\end{array}$ & $\begin{array}{l}\text { decarburized steel } \\
\text { from white cast iron, } \\
\text { forged }\end{array}$ & \\
\hline 9 & FWC03 & & & $\begin{array}{l}\text { U-shaped } \\
\text { implement } \\
\text { cap } \\
\end{array}$ & $\begin{array}{l}-4 \text { th/-2nd } \\
\text { century }\end{array}$ & $\begin{array}{c}\text { Fujian } \\
\text { (southeast } \\
\text { coast) } \\
\end{array}$ & pearlite+ferrite matrix with graphite. & malleable cast iron & \\
\hline 10 & FWC05 & $\begin{array}{l}\mathrm{T} 287 \\
\text { (3):39 }\end{array}$ & & axehead & $\begin{array}{l}-4 \text { th/-2nd } \\
\text { century }\end{array}$ & $\begin{array}{l}\text { Fujian } \\
\text { (southeast } \\
\text { coast) }\end{array}$ & $\begin{array}{c}\text { ferrite, grain size grade } 5 \text {, some carbides } \\
\text { precipitated in the ferritic grains, few single-phased } \\
\text { inclusions. }\end{array}$ & $\begin{array}{c}\text { decarburized steel } \\
\text { from white cast iron, } \\
\text { forged }\end{array}$ & \\
\hline
\end{tabular}




\begin{tabular}{|c|c|c|c|c|c|c|c|c|c|}
\hline No. & Lab No. & Context & $\begin{array}{c}\text { Cutting } \\
\text { point }\end{array}$ & Type & Date & Area & Description * & Conclusion & Source \\
\hline 11 & FWC06 & $\begin{array}{l}\text { T287 } \\
\text { (3):34 }\end{array}$ & & axehead & $\begin{array}{l}-4 \text { th/-2nd } \\
\text { century }\end{array}$ & $\begin{array}{l}\text { Fujian } \\
\text { (southeast } \\
\text { coast) }\end{array}$ & $\begin{array}{l}\text { ferrite+pearlite in the cutting edge area, } 0.2 \% \\
\text { carbon, few single-phased inclusions. Ferrite in the } \\
\text { socket area, grain size grade } 5 .\end{array}$ & $\begin{array}{c}\text { two pieces of } \\
\text { decarburized steel } \\
\text { from white cast iron, } \\
\text { forged }\end{array}$ & \\
\hline 12 & FWC16 & T8III(3): 1 & & sword & $\begin{array}{l}-4 \text { th/-2nd } \\
\text { century }\end{array}$ & $\begin{array}{l}\text { Fujian } \\
\text { (southeast } \\
\text { coast) }\end{array}$ & $\begin{array}{l}\text { martensite, some bandings caused by trace element, } \\
\text { single-phased inclusion stringers. }\end{array}$ & fined steel, forged & \\
\hline 13 & FWC17 & & & sword & $\begin{array}{l}-4 \text { th/-2nd } \\
\text { century }\end{array}$ & $\begin{array}{l}\text { Fujian } \\
\text { (southeast } \\
\text { coast) }\end{array}$ & $\begin{array}{c}\text { uneven structure, } 3-5 \text { layers of differnet carbon } \\
\text { content, Widmanstätten structure in high carbon } \\
\text { content area, } 0.7 \% \text { carbon with some spheridized } \\
\text { pearlite, ferrite+pearlite in lower carbon content } \\
\text { areas, } 0.4 \% \text { carbon, some single-phased inclusion } \\
\text { stringers. }\end{array}$ & fined steel, forged & \\
\hline 14 & $1: 4249$ & $\begin{array}{c}\text { Tomb of } \\
\text { Liusheng }\end{array}$ & body? & sword & $\begin{array}{c}165- \\
113 \mathrm{BCE}\end{array}$ & $\begin{array}{l}\text { Hebei } \\
\text { (Central } \\
\text { Plain) }\end{array}$ & $\begin{array}{l}5 \text { layers for the central ridge, and } 4 \text { layers in the } \\
\text { blade areas. Higher carbon layer about } 0.6-0.7 \% \\
\text { carbon, and lower carbon layers about } 0.3 \% \text { carbon. } \\
\text { Martensite on the cutting edge. 'carbon-free bainite' } \\
\text { (lower bainite) on the surface. }\end{array}$ & $\begin{array}{l}\text { carburized steel from } \\
\text { bloomery iron, } \\
\text { quenched }\end{array}$ & \multirow{2}{*}{$\begin{array}{l}\text { (Yu and Qian } \\
\text { 2011) }\end{array}$} \\
\hline 15 & $1: 5105$ & $\begin{array}{l}\text { Tomb of } \\
\text { Liusheng }\end{array}$ & section & sword & $\begin{array}{c}165- \\
113 \mathrm{BCE}\end{array}$ & $\begin{array}{l}\text { Hebei } \\
\text { (Central } \\
\text { Plain) }\end{array}$ & $\begin{array}{l}\text { lower carbon content layer about } 0.1-0.2 \% \text {, higher } \\
\text { carbon content layer about } 0.5-0.6 \% \text {, surface } \\
\text { carburized, higher than } 0.6 \% \text { carbon, martensite } \\
\text { observed. Layers are thin due to the repeatedly } \\
\text { forging process. Inclusion size is small, the biggest } \\
\text { is } 0.05-0.1 \mathrm{~mm} \text {. }\end{array}$ & $\begin{array}{l}\text { carburized steel from } \\
\text { bloomery iron, } \\
\text { partially quenched }\end{array}$ & \\
\hline 16 & HXS-4 & M37:4 & $\begin{array}{l}\text { broken } \\
\text { section }\end{array}$ & sword & $\begin{array}{l}\text { 202BCE - } \\
\text { 20CE }\end{array}$ & $\begin{array}{l}\text { Henan } \\
\text { (Central } \\
\text { Plain) }\end{array}$ & $\begin{array}{l}\text { trace of forging, indistinct pearlite, forged from } \\
\text { eutectoid steel. }\end{array}$ & $\begin{array}{l}\text { decarburized steel } \\
\text { from white cast iron, } \\
\text { forged }\end{array}$ & $\begin{array}{l}\text { (Rong et al. } \\
\text { 2013) }\end{array}$ \\
\hline 17 & & M311:2 & & sword & $\begin{array}{c}300- \\
221 \mathrm{BC}\end{array}$ & $\begin{array}{c}\text { Guizhou } \\
\text { (southwest) }\end{array}$ & $\begin{array}{l}\text { badly corroded with no metal remaining, some } \\
\text { trace of ferrite and pearlite can be seen in the } \\
\text { corrosion with single-phased slag stringers. }\end{array}$ & $\begin{array}{l}\text { decarburized steel } \\
\text { from white cast iron }\end{array}$ & \multirow{2}{*}{$\begin{array}{l}\text { (Chen et al. } \\
\text { 2008a) }\end{array}$} \\
\hline 18 & & M284:3 & & $\begin{array}{l}\text { U-shaped } \\
\text { implement } \\
\text { cap }\end{array}$ & $\begin{array}{l}202- \\
150 \mathrm{BC}\end{array}$ & $\begin{array}{c}\text { Guizhou } \\
\text { (southwest) }\end{array}$ & $\begin{array}{l}\text { badly corroded, ferrite matrix with cotton-like } \\
\text { graphite can be seen in the corrosion in the core, a } \\
\text { decarburization layer on the edge. }\end{array}$ & $\begin{array}{c}\text { malleable cast iron, } \\
\text { decarburized from } \\
\text { white cast iron }\end{array}$ & \\
\hline
\end{tabular}


Anonymous (1975) Yixian Yanxiadu 44 hao Muzang Tieqi Jinxiang Kaocha Chubu Baogao

[Preliminary study on the iron artifacts excavated from tomb 44 of the Yanxiadu site] Kaogu 4:241-243

Bai Y (2005) Xianqin Lianghan Tieqi de Kaoguxue Yanjiu. [Archaeological Study of Iron Objects in China Before the 3rd Century AD]. Kexue Chubanshe, Beijing

Beijing UoIaST (1989) Dabaotai Hanmu Tieqi Jinxiang Jiancha Baogao [A metallurgraphic study of iron objects excavated from Dabaotai tomb of the Han Dynasty]. In: Excavation of Western Han Tomb at Dabaotai, Beijing. Wenwu Chubanshe, Beijing, pp 125-127

Chen J, Han R, Wan X, Li Y (2001) Beipiao Lamadong Mudi Chutu Tieqi de Jinxiang Shiyan Yanjiu [The metallographic study on the ferrous artifacts unearthed from tombs of Lamadong site in Beipiao county, Liaoning province] Wenwu 12:71-79

Chen J, Huang Q, Li Y, Han R (2008a) Metallurgical studies on the excavated iron objects from tombs at Kele, Hezhang, Guizhou. In: The excavation report of Hezhang Kele in 2000. Wenwu Chubanshe, Beijing, pp 195-206

Chen J, Yang C, Zhang H, Lin F (2008b) Fujian Wuyishan Chengcun Hancheng Chutu Tieqi de Jinxiang Shiyan Yanjiu [Metallographic study on the iron objects excavated from the Han dynasty city at Chengcun, Wuyishan, Fujian province] Wenwu 3:88-96

Han R (1998) Zhongguo Zaoqi Tieqi de Jinxiangxue Yanjiu [An Metallographic Study on Early Iron Objects of China (before the 5th century BC)] Wenwu 2:87-96

Han R, Ke J (2007) Zhongguo Kexue Jishushi Kuangyejuan [A History of Science and Technology in China, Mining and Metallurgy]. Kexue Chubanshe, Beijing

Li X (2011) Gu Dianguo Jinshu Jishu Yanjiu. [Metallurgical Study of Ancient Dian]. Kexue Chubanshe, Beijing

Li Y, Yang S, Ma C, Yu J (2016) A cast-iron bridge pier dated 96 BCE found in Sichuan, China. translated by Donald B Wagner Historical Metallurgy 49:26-36

Liu B (2013) Study on the Qin and Han tombs at the Qiaogoutou cemetery site. Sichuan University

Liu H, Chen J, Mei J, Jia J, Shi L (2014) A view of iron and steel making technology in the Yan region during the Warring States period and the Han dynasty: scientific study of iron objects excavated from Dongheishan site, Heibei province, China Journal of Archaeological Science 47:53-63

Liu Z (2012) Xiangjiaba Shuidianzhan Yanmoqu (Sichuan) Kaogu Gongzuo Zhuyao Chengguo

[Main achievements of the archaeological work in the inundated area of the Xiangjiaba dam (Sichuan province)] Sichuan Wenwu 1:3-5

Lu Z, Ye X, Wang Y, Du Y, Wang X, Bai R, Zheng S (1980) Mancheng Hanmu Fajue Baogao.

[Excavation of Han tomb at Mancheng]. Wenwu Chubanshe, Beijing

Ma C (2011) Preliminary study on iron smelting sites in Chengdu plain. Sichuan University

Rong Y, Luo W, Wei G, Song G, Wang C (2013) Shenmingpu Yizhi Chutu Tieqi de Gongyi

Kaocha ]Study on manufacturing technique for iron artifacts unearthed from the Shenmingpu site] Sciences of Conservation and Archaeology 25 No.3:64-70

Scott DA (2013) Ancient Metals: Microstructure and Metallurgy Vol IV, Iron and Steel. (C David Arthur Scott, Charleston

SiMa Q (1982) Shi Ji [Records of the historian] vol 129. Zhonghua Shujv, Beijing

Wagner DB (1993) Iron and Steel in Ancient China. E.J. Brill, Leiden

Wagner DB (2007) Science and civilisation in China vol 5, part 11. Ferrous Metallurgy. Cambridge University Press, Cambridge

Yu M, Qian W (2011) Jinxiang Fenxi Jishu zai Yanjiu Qinhan Tiebingqi Zhizuo Jishu zhong de Yingyong [Applications of Metallographic Analysis Technology in Qin and Han Iron Weapons Production Technology] Technology \& Development of Chemical Industry 40 No.1:31-36 
Zhou W, Liu S, Chen J (2016) Discovery and Study of Metallurgical Crucibles in Ancient China [in Chinese with an English abstract] Studies in the History of Natural Sciences 35 No.3:358-370 